\title{
МОЛОДЫЕ ИССЛЕДОВАТЕЛИ
}

DOI: $10.15838 /$ esc.2017.2.50.15

УДК 338.48 , ББК 65.433

(с) Леонидова Е.Г.

\section{Развитие внутреннего туризма в регионе}

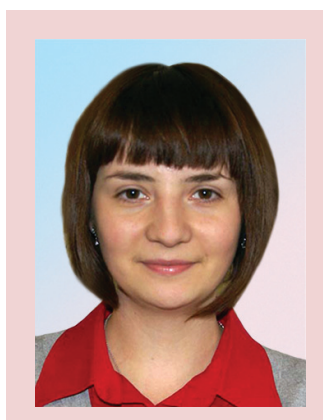

Екатерина Георгиевна

ЛЕОНИДОВА

Институт социально-экономического развития территорий

Российской академии наук

Вологда, Российская Федерация, ул. Горького, д. 56а

E-mail: leo_leg_8509@mail.ru

Аннотация. Туризм является отраслью, которая оказывает значительное влияние на социальноэкономическое развитие территорий. Данный вид народнохозяйственной деятельности характеризуется мультипликативным эффектом, генерируя образование доходов в смежных отраслях экономики. Среди видов туризма ключевую роль стал играть внутренний туризм как основной источник финансовых поступлений от туристской деятельности. В регионах Российской Федерации внутренний туризм развит слабо, что связано с несовершенной инфраструктурой отрасли, несоответствием цены на туристские продукты их качеству, а также недостатком квалифицированных кадров. В последнее время особую значимость для данного направления приобрело воздействие внешних факторов, таких как неспокойная геополитическая обстановка в ряде стран, кризисные явления в экономике, запрет выезда россиян на популярные зарубежные курорты. Вопросы развития внутреннего туризма отражены в работах Д.Р. Макеевой, Е.В. Семеновой, Н.В. Масловой, Л.И. Черниковой, Г.Р. Фаизовой. Целью исследования является научное обоснование направлений, обеспечивающих развитие внутреннего туризма в регионе с учетом влияния внешних факторов. При этом используются научные методы сравнения, обобщения, анализа, синтеза, PEST-анализа, метод экспертного опроса. На основании анализа статистических данных выявлено сокращение числа поездок россиян в туристских целях с одновременным ростом их спроса на гостиничные услуги внутри страны. Кроме того, имеющийся в настоящее время туристический потенциал позволяет развивать широкий спектр видов туризма для вну-

Для цитирования: Леонидова, Е.Г. Развитие внутреннего туризма в регионе / Е.Г. Леонидова // Экономические и социальные перемены: факты, тенденции, прогноз. - 2017. - Т. 10. - № 2. - C. 271-283. DOI: 10.15838/esc/2017.2.50.15

For citation: Leonidova E.G. Domestic tourism development in a region. Economic and Social Changes: Facts, Trends, Forecast, 2017, volume 10, no. 2, pp. 271-283. DOI: 10.15838/esc/2017.2.50.15 
трениих туристов. Как выяснилось, препятствуют этому недостаток в регионе турпродуктов, привлекающих внутренних туристов, несовершенство туристической инфраструктуры и отсутствие у населения денежных средств на осуществление туристической поездки. В заключении статьи определены на основе PEST-анализа направления, способствующие наиболее эффективному развитию внутреннего туризма в регионе, учитывающие экономическую и геополитическую конъюнктуру.

Ключевые слова: туризм, внутренний туризм, регион, экономика.

Введение. Для российских регионов, характеризующихся монопрофильностью структуры экономики, актуальной задачей является поиск внутренних источников развития. При этом особое значение для территории приобретает развитие отраслей, которые обладают мультипликативным эффектом, то есть положительно влияют на смежные отрасли народного хозяйства, создавая новые рабочие места, повышая мобильность населения, а также вклад в бюджеты всех уровней, обеспечивая экономический рост территории. В качестве сектора экономики, обладающего подобными характеристиками, может рассматриваться туризм. Согласно данным Всемирной туристской организации, на эту сферу приходится 9,8\% мирового валового внутреннего продукта, каждое 11-е рабочее место [18;20]. Туристская отрасль индуцирует развитие до 32 смежных отраслей народного хозяйства. Кроме того, она выступает в качестве способа диверсификации экономики, обусловливая повышение устойчивости социально-экономических систем. При этом следует отметить, что развитие данной отрасли не исключает традиционного пути развития производственного сектора экономики (машиностроение, обрабатывающая промышленность, нефтегазовый сектор и т.д.), а способствует более эффективному использованию имеющегося у региона потенциала, в частности туристских ресурсов.

В 2014-2016 гг. в структуре туристического рынка Российской Федерации про- изошли серьезные изменения, связанные с сокращением выездного турпотока вследствие существенного снижения курса национальной валюты, влиянием экономического кризиса, длительным запретом на продажу туров для россиян по ведущим выездным направлениям (Турция и Египет), а также неспокойной геополитической обстановкой в мире. Это обусловило сокращение спроса россиян на зарубежные направления и увеличило интерес к отдыху внутри страны.

В Российской Федерации внутренний туризм, предполагающий перемещения граждан внутри страны в целях туризма, развит не в полной мере. Между тем в экономике зарубежных стран (США, Китай, Япония и др.) он обеспечивает до $80 \%$ денежных поступлений в структуре видов туризма (рис. 1).

Таким образом, актуальность данного исследования обусловлена противоречием между высокой социально-экономической значимостью сферы внутреннего туризма и недостаточным уровнем ее развития в регионах РФ в современных экономических условиях. Целью исследования является научное обоснование направлений, обеспечивающих развитие внутреннего туризма в регионе с учетом влияния внешних факторов. Для ее достижения были рассмотрены имеющиеся подходы к понятию «внутренний туризм», выполнен анализ развития данной сферы в российских регионах, а также определено влияние на нее внешних факторов. 
Рисунок 1. Туристские расходы резидентов и международных туристов в 2015 г., млрд. долл. США [17; 20].

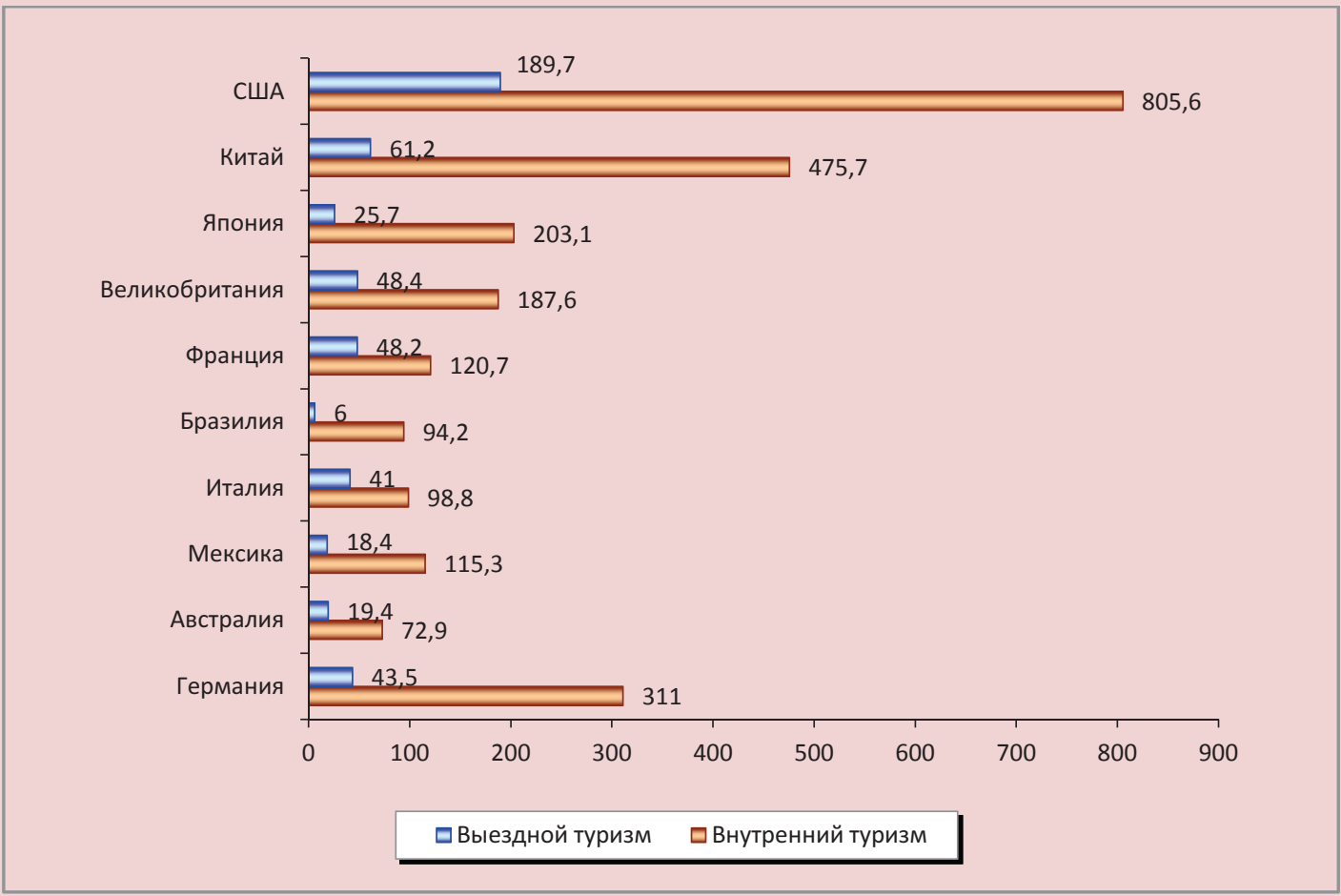

Методы исследования. Методологические подходы к исследованию базируются на общенаучных методах сравнения, обобщения, анализа, синтеза, PEST-анализа, методе экспертного опроса. Информационную базу исследования составили труды отечественных и зарубежных экономистов в области методических и практических вопросов управления развитием туризма с учетом региональных особенностей. Вопросы регионального развития освещены в трудах таких ученых, как А.Г. Гранберг, С.Ю. Глазьев, Р.С. Гринберг и другие $[2 ; 10 ; 12]$. Теоретические и практические походы к развитию туризма широко исследованы и в работах зарубежных ученых, которые применительно к внутреннему туризму рассматривают значимость его развития для экономики территории, фокусируя свое внимание на его проблемах
[19; 21]. Влияние туризма на экономику на региональном уровне отражено в работах отечественных ученых Т.Н. Григоренко, Л.Н. Казьминой, В.И. Кружалина, К.В. Кружалина, Н.В. Шабалиной, Т.В. Усковой и др. $[1 ; 3 ; 6 ; 11 ; 13-15 ; 19 ; 21]$. Проблемы развития внутреннего туризма изучали Д.Р. Макеева, Е.В. Семенова, Н.В. Маслова, Л.И. Черникова, Г.Р. Фаизова и другие ученые [7; 9; 6]. Вместе с тем анализ вышеперечисленных работ позволил заключить, что способы стимулирования развития внутреннего туризма на региональном уровне остаются малоизученными. Кроме того, в них нечетко прослеживается связь между внутренним туризмом и региональным развитием.

Результаты исследования. Несмотря на широкое применение термина «внутренний туризм», он до сих пор не имеет общепри- 
знанного определения, учитывающего и включающего все его особенности. Согласно Ф3 «Об основах туристской деятельности в Российской Федерации» № 132 от 24.11.1996 г., внутренний туризм определяется как туризм в пределах территории Российской Федерации лиц, постоянно проживающих в Российской Федерации. В.А. Квартальнов предлагает понимать под внутренним туризмом временный выезд граждан конкретной страны с постоянного места жительства в пределах национальных границ той же страны для отдыха, удовлетворения познавательных интересов, занятий спортом и в других туристских целях [4].

Рассмотренные определения конкретизируют субъектов внутреннего туризма и их цель, подчеркивают его территориальный аспект, однако не учитывают его экономического и социального влияния на развитие территорий. Хотя известно, что внутренний туризм для экономики региона более значим, чем въездной и выездной, поскольку производство и потребление туристского продукта на территории региона стимулирует местных производителей к расширению производства товаров и услуг и содействует приросту конечного потребления, увеличивая таким образом валовой региональный продукт. Помимо создания новых рабочих мест и удовлетворения потребностей населения в отдыхе, познании и пр., социальная функция внутреннего туризма состоит в развитии человеческого потенциала региона. Так, инфраструктура туризма, включающая сеть коллективных средств размещения, питания, развлечений, оздоровления и спорта, способствует снятию психического и эмоционального напряжения, укреплению здоровья жителей как региона, так и страны в целом.

В целях социально-экономического развития регионов, характеризующихся снижением макроэкономических показателей, необходим поиск и обоснование внутренних источников роста экономики. Учитывая вышесказанное, отметим, что внутренний туризм может рассматриваться в качестве фактора роста экономики, поскольку производит на основе имеющихся ресурсов туристский продукт, потребление которого туристами позволяет развиваться экономике региона. Представленный подход не противоречит существующим направлениям изучения внутреннего туризма, а дает возможность дополнить сущность данного явления, отражая его роль в социально-экономическом развитии региона.

Анализ статистической информации свидетельствует о том, что новые экономические условия обусловили снижение спроса российских туристов на туры в зарубежные страны. Так, общее число выездных туристских поездок в 2015 году по сравнению с 2014 годом сократилось почти на $20 \%$ (табл. 1).

За период с 2010 по 2015 год отмечен рост числа россиян, останавливающихся в гостиницах и иных средствах проживания (пансионатах, лагерях, кемпингах и пр.), по всем федеральным округам Российской Федерации (табл. 2). Так, почти в 2 раза увеличилось значение данного показателя в Южном федеральном округе, что объясняется ростом курса национальной валюты и закрытием ведущих пляжных направлений - Турции и Египта. Следует отметить, что за 2014-2015 гг., благодаря вхождению Республики Крым в состав РФ, количество постояльцев в средствах размещения возросло в 4 раза. Эти данные свидетельствуют и о растущем спросе граждан РФ на гостиничные услуги, в том числе обусловленном интересом к внутренним туристским ресурсам. 
Таблица 1. Страны с наибольшим числом въездов российских туристов

\begin{tabular}{|c|c|c|c|c|c|}
\hline \multirow{2}{*}{ Страна } & \multicolumn{2}{|c|}{ Число поездок, тыс. } & \multirow{2}{*}{$\begin{array}{c}\text { Изменение } \\
\%\end{array}$} & \multicolumn{2}{|c|}{ Место в рейтинге по числу поездок } \\
\hline & 2014 г. & 2015 г. & & 2014 & 2015 \\
\hline Финляндия & 4283 & 3067 & $-28,4$ & 1 & 4 \\
\hline Турция & 4216 & 3460 & $-17,9$ & 2 & 2 \\
\hline Казахстан & 3330 & 3125 & $-6,2$ & 3 & 3 \\
\hline Абхазия & 3282 & 3824 & 16,5 & 4 & 1 \\
\hline Египет & 2880 & 2244 & $-22,1$ & 5 & 5 \\
\hline Украина & 2558 & 1657 & $-35,2$ & 6 & 6 \\
\hline Эстония & 1775 & 1477 & $-16,8$ & 7 & 7 \\
\hline Китай & 1731 & 1284 & $-25,8$ & 8 & 9 \\
\hline Польша & 1608 & 1322 & $-17,8$ & 9 & 8 \\
\hline Германия & 1435 & 1111 & $-22,6$ & 10 & 10 \\
\hline Тайланд & 1250 & 675 & $-46,0$ & 11 & 13 \\
\hline Греция & 1165 & 634 & $-45,6$ & 12 & 16 \\
\hline Испания & 1140 & 693 & $-39,2$ & 13 & 12 \\
\hline Италия & 994 & 662 & $-33,4$ & 14 & 14 \\
\hline Литва & 798 & 743 & $-6,9$ & 15 & 11 \\
\hline ОАЭ & 737 & 472 & $-35,9$ & 16 & 19 \\
\hline Азербайджан & 734 & 584 & $-20,4$ & 17 & 17 \\
\hline Кипр & 670 & 550 & $-17,9$ & 18 & 18 \\
\hline Болгария & 559 & 413 & $-26,1$ & 19 & 20 \\
\hline Грузия & 532 & 651 & 22,3 & 20 & 15 \\
\hline Франция & 521 & 408 & $-21,7$ & 21 & 21 \\
\hline Чехия & 513 & 361 & $-29,7$ & 22 & 22 \\
\hline Латвия & 404 & 312 & $-22,8$ & 23 & 24 \\
\hline Израиль & 361 & 299 & $-17,2$ & 24 & 25 \\
\hline Южная Осетия & 358 & Менее 321 & Менее $-10,3$ & 25 & Ниже 25 \\
\hline Вьетнам & 352 & 321 & $-8,8$ & 26 & 23 \\
\hline Другие страны & 5088 & 4041 & $-20,6$ & $x$ & $x$ \\
\hline
\end{tabular}

Таблица 2. Численность граждан Российской Федерации, размещенных в коллективных средствах размещения, тыс. чел.

\begin{tabular}{|l|c|c|c|c|c|c|c|}
\hline \multicolumn{1}{|c|}{ Территория } & 2010 & 2011 & 2012 & 2013 & 2014 & 2015 & $\begin{array}{c}2015 \text { к 2010, } \\
\text { в \% }\end{array}$ \\
\hline Российская Федерация & 27166,7 & 29310,2 & 31798,4 & 32560,6 & 33798,5 & 43656,9 & 161 \\
\hline Центральный федеральный округ & 7759,5 & 8303,2 & 9029,3 & 9418,3 & 9660,9 & 11921,4 & 154 \\
\hline Южный федеральный округ & 3434,2 & 3472,3 & 3651,4 & 3681,5 & 4809,4 & 6846,8 & 199 \\
\hline Приволжский федеральный округ & 4460,2 & 4914,2 & 5635,0 & 5850,9 & 5707,1 & 6777,1 & 152 \\
\hline Северо-Западный федеральный округ & 3546,0 & 3936,0 & 4051,2 & 4051,9 & 4209,1 & 5415,1 & 153 \\
\hline Сибирский федеральный округ & 3138,8 & 3402,1 & 3608,7 & 3867,3 & 3519,8 & 4485,0 & 143 \\
\hline Уральский фредеральный округ & 2201,0 & 2543,7 & 2987,6 & 2979,2 & 2784,4 & 3054,6 & 139 \\
\hline Дальневосточный федеральный округ & 1607,9 & 1698,0 & 1760,9 & 1609,0 & 1518,9 & 2028,6 & 126 \\
\hline Крымский федеральный округ & - & - & - & - & 442,1 & 1825,1 & 413 \\
\hline Северо-Кавказский федеральный округ & 1019,2 & 1040,6 & 1074,4 & 1102,5 & 1146,7 & 1303,2 & 128 \\
\hline Источник: данные Росстата. & \multicolumn{7}{|l}{} \\
\hline
\end{tabular}


20916 мнению экспертов Высшей школы экономики, более дешевые поездки в пределах страны, переход к стратегиям экономии могут стать фактором роста рынка внутреннего российского туризма [8].

Одним из регионов, наиболее благоприятных для развития туристической деятельности, привлекающих внутренних туристов, является Северо-Западный федеральный округ, в котором сконцентрированы культурно-исторические и природные ресурсы, служащие основой для создания разнообразных турпродуктов. В нем расположено самое большое в стране количество памятников культуры и природы, находящихся под охраной ЮНЕСКО (табл. 3).

Кроме того, по состоянию на 2014 г. он занимал второе место в РФ после Центрального федерального округа по числу объектов культурного наследия. Туристические ресурсы СЗФО позволяют развивать культурно-исторический, экологический, событийный, сельский и другие виды туризма, привлекающие в том числе внутренних туристов.

Однако имеющийся в настоящее время потенциал реализуется неэффективно. Так, анализ продаж туров показал, что в $2010-$ 2015 гг. доля туров, проданных турфирмами СЗФО в регионы РФ, не высока (табл. 4). Например, в 2015 году значение данного показателя составило $32 \%$ от общего объема реализованных турпакетов.

Число коллективных средств размещения (КСР) в этом регионе увеличивается. В период с 2010 по 2015 г. оно выросло почти на $34 \%$ (табл. 5). Причем рост данного показателя отмечен во всех субъектах СЗФО: только в Калининградской области - в 3,5 раза. Такая тенденция обусловлена интересом со стороны представителей гостиничного бизнеса к строительству новых объектов.

Таблица 3. Список объектов Всемирного культурного наследия ЮНЕСКО, расположенных на территории СЗФО

\begin{tabular}{|l|c|c|c|}
\hline \multicolumn{1}{|c|}{ Название объекта } & Местоположение объекта & $\begin{array}{c}\text { Год внесения } \\
\text { в список }\end{array}$ & $\begin{array}{c}\text { № 0бъекта } \\
\text { в списке }\end{array}$ \\
\hline $\begin{array}{l}\text { Исторический центр Санкт-Петербурга и связанные с ним } \\
\text { комплексы памятников }\end{array}$ & г. Санкт-Петербург & 1990 & 540 \\
\hline Архитектурный ансамбль Кижского погоста & Республика Карелия & 1990 & 544 \\
\hline Исторические памятники Новгорода и его окрестностей & Новгородская область & 1992 & 604 \\
\hline Культурный и исторический ансамбль «Соловецкие острова» & Архангельская область & 1992 & 632 \\
\hline Девственные леса Коми & Республика Коми & 1995 & 719 \\
\hline Ансамбль Ферапонтова монастыря & Вологодская область & 2000 & 982 \\
\hline Куршская коса & Калининградская область \\
(совместно с Литвой) & 2003 & 994 \\
\hline Геодезическая дуга Струве & Ленинградская область & 2005 & 1187 \\
\hline $\begin{array}{l}\text { Источник: осициальный сайт 0ОН по вопросам образования, науки и культуры (ЮнЕСКо). - Режим доступа: httр://whc.unesco. } \\
\text { огg/ (дата обращения: 01.08.2016). }\end{array}$ \\
\hline
\end{tabular}

Таблица 4. Количество туров, проданных туристскими фирмами СЗФО, тыс. шт.

\begin{tabular}{|l|c|c|c|c|c|c|c|}
\hline \multicolumn{1}{|c|}{ Число туров } & 2010 & 2011 & 2012 & 2013 & 2014 & 2015 & $\begin{array}{c}2015 \text { к 2010, } \\
\text { в \% }\end{array}$ \\
\hline Всего & 545,4 & 626,4 & 790,3 & 1029,1 & 496,6 & 156,2 & 28,6 \\
\hline из них по территории России & 115,2 & 89,8 & 141,3 & 143,4 & 147,0 & 49,5 & 43,0 \\
\hline по зарубежным странам & 383,8 & 468,2 & 616,1 & 834,0 & 284,8 & 102,8 & 26,8 \\
\hline Источник: данные Росстата.
\end{tabular}


Таблица 5. Количество коллективных средств размещения в СЗФО, ед.

\begin{tabular}{|c|c|c|c|c|c|c|c|}
\hline Территория & 2010 & 2011 & 2012 & 2013 & 2014 & 2015 & $\begin{array}{c}2015 \text { к } 2010, \\
\text { B \% }\end{array}$ \\
\hline Северо-Западный федеральный округ & 1454 & 1532 & 1893 & 1504 & 1556 & 1942 & 133,6 \\
\hline г. Санкт-Петербург & 360 & 382 & 434 & 382 & 389 & 412 & 114,4 \\
\hline Ленинградская область & 265 & 322 & 393 & 253 & 269 & 274 & 103,4 \\
\hline Калининградская область & 57 & 57 & 81 & 109 & 109 & 201 & 352,6 \\
\hline Вологодская область & 145 & 142 & 171 & 131 & 120 & 200 & 137,9 \\
\hline Республика Карелия & 105 & 125 & 149 & 129 & 133 & 182 & 173,3 \\
\hline Архангельская область & 124 & 120 & 142 & 112 & 145 & 166 & 133,9 \\
\hline Мурманская область & 136 & 127 & 183 & 118 & 119 & 143 & 105,1 \\
\hline Республика Коми & 97 & 76 & 97 & 86 & 87 & 132 & 136,1 \\
\hline Новгородская область & 92 & 97 & 135 & 110 & 111 & 126 & 137,0 \\
\hline Псковская область & 73 & 84 & 108 & 74 & 74 & 106 & 145,2 \\
\hline
\end{tabular}

Таблица 6. Коэффрициент загрузки гостиниц и аналогичных средств размещения в Северо-Западном фредеральном округе

\begin{tabular}{|l|c|c|c|c|c|c|}
\hline \multicolumn{1}{|c|}{ Территория } & 2010 & 2012 & 2013 & 2014 & 2015 & $\begin{array}{c}2015 \text { к 2010, } \\
\text { в \% }\end{array}$ \\
\hline г. Санкт-Петербург & 0,39 & 0,44 & 0,37 & 0,35 & 0,49 & 125,6 \\
\hline Северо-Западный федеральный округ & 0,33 & 0,36 & 0,33 & 0,30 & 0,36 & 109,1 \\
\hline Новгородская область & 0,33 & 0,30 & 0,28 & 0,28 & 0,33 & 100,0 \\
\hline Архангельская область & 0,43 & 0,37 & 0,25 & 0,33 & 0,33 & 76,7 \\
\hline Калининградская область & 0,15 & 0,34 & 0,33 & 0,20 & 0,32 & 213,3 \\
\hline Республика Карелия & 0,29 & 0,29 & 0,29 & 0,27 & 0,30 & 103,4 \\
\hline Республика Коми & 0,31 & 0,38 & 0,41 & 0,33 & 0,30 & 96,8 \\
\hline Псковская область & 0,32 & 0,32 & 0,27 & 0,19 & 0,26 & 81,3 \\
\hline Ленинградская область & 0,27 & 0,29 & 0,28 & 0,20 & 0,25 & 92,6 \\
\hline Мурманская область & 0,28 & 0,26 & 0,32 & 0,25 & 0,25 & 89,3 \\
\hline Вологодская область & 0,16 & 0,18 & 0,23 & 0,22 & 0,23 & 143,8 \\
\hline Источник: Культура, туризм и отдых в Псковской области. 2015: стат. сб. // Псковстат. - Псков, 2015. - С. 36. \\
\hline
\end{tabular}

В то же время, как показал анализ коэффициента загрузки КСР, их заполняемость в СЗФО достаточно низкая - 0,36 (табл. 6). При этом за исследуемый период значение данного показателя в Архангельской, Псковской, Ленинградской, Мурманской областях, Республике Коми уменьшилось.

Данный факт можно объяснить тем, что на рынке гостиничных услуг имеет место ситуация, которая характеризуется высокой конкуренцией со стороны предприятий, предоставляющих услуги проживания, и недостатком туристского продукта, способного удовлетворить потребителей и, таким образом, задержать туриста в месте пребывания, загрузив гостиницы и аналогичные средства размещения. В большинстве субъектов СЗФО турфирмами предлагаются однотипные туры, основанные только на осмотре историко-культурных достопримечательностей.

Кроме того, растущий спрос населения РФ на услуги средств размещения тормозится сокращением его реальных денежных доходов и уровнем заработной платы. В течение 2012 - 2015 гг. отмечена тенденция к снижению данных показателей (рис. 2). 
Рисунок 2. Динамика показателей, характеризующих уровень жизни населения РФ

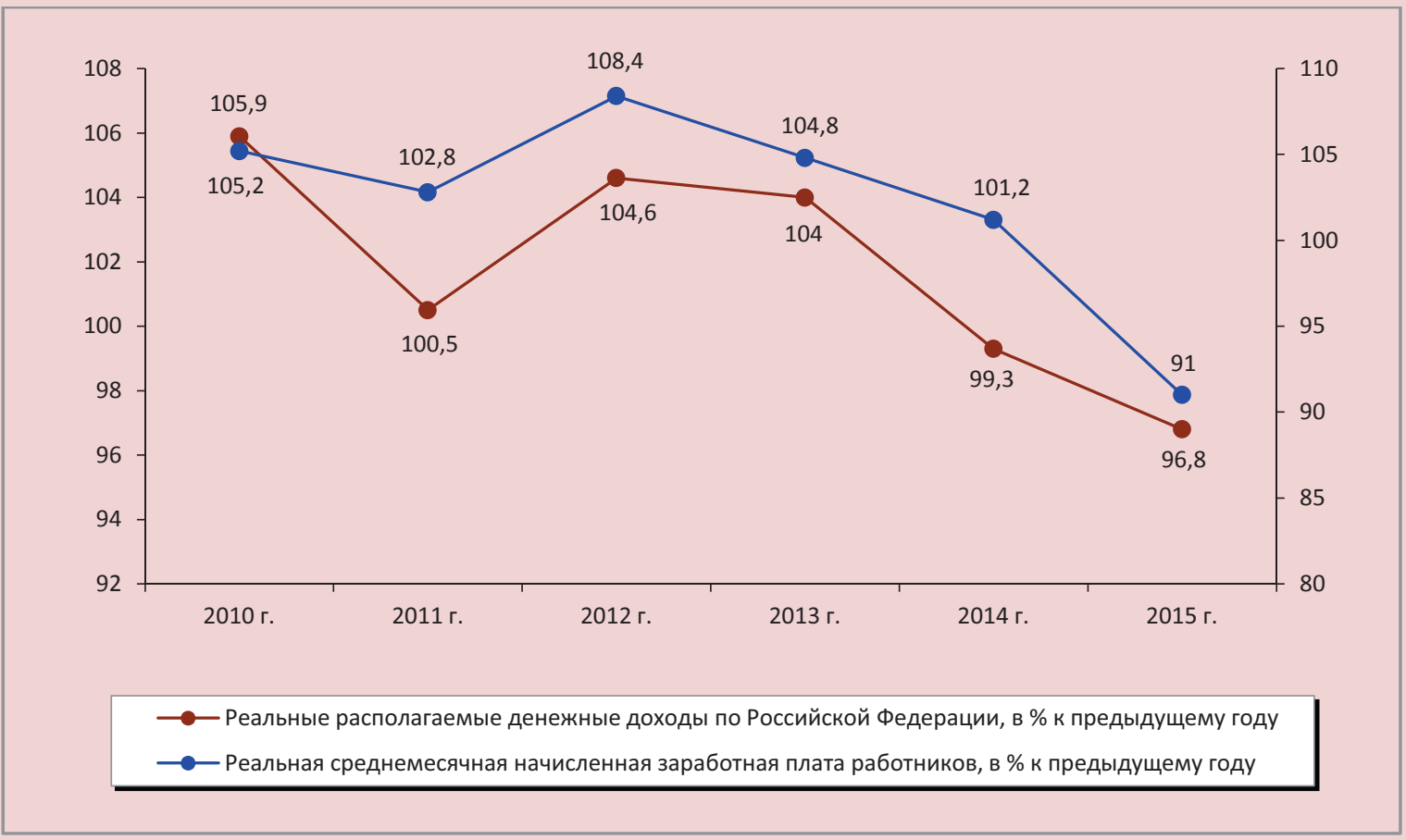

Источник: данные Федеральной службы государственной статистики РФ. - Режим доступа:www.gks.ru/free_doc/ new_site/population/trud/sr-zarplata/t5.doc; http://www.gks.ru/free_doc/new_site/population/urov/urov_12kv.htm

Другой проблемой развития внутреннего туризма в регионе является несоответствие инфраструктуры мировым стандартам качества и уровня обслуживания. Так, например, здесь только половина всего дорожного полотна $(53,3 \%)$ имеет качественное покрытие (табл. 7). Этот факт снижает транспортную доступность внутренних туристов к достопримечательностям региона.

Во многих субъектах Российской Федерации отсутствует система классификации гостиниц, пляжей, горнолыжных объектов и других туристических объектов, что влияет на качество предоставляемых услуг. Между тем классификация гостиничных предприятий является одним из важнейших механизмов управления качеством обслуживания, так как дает возможность объективно оценить уровень услуг, подтвердить их безопасность для потребителя [5].
Таким образом, развитие внутреннего туризма в Российской Федерации в целом и в Северо-Западном федеральном округе в частности сопряжено с определенными проблемами. Среди всех субъектов СЗФО Вологодская область характеризуется высоким культурно-историческим потенциалом, служащим для развития широкого спектра видов туристической деятельности.

В ходе анализа воздействия внешних факторов на развитие данного направления туристского рынка использовался метод PEST-анализа, который базировался на агрегировании результатов экспертного опроса. В состав группы экспертов вошли специалисты Департамента культуры и туризма Вологодской области, представители турфирм, занимающихся разработкой туров внутри региона, а также научные сотрудники ИСЭРТ РАН, представители 
Таблица 7. Некоторые показатели качества автомобильных дорог за 2015 г.

\begin{tabular}{|c|c|c|}
\hline Территория & $\begin{array}{l}\text { Общая } \\
\text { протяженность } \\
\text { автодорог, км }\end{array}$ & $\begin{array}{c}\text { Удельный вес автомобильных дорог общего пользования } \\
\text { с усовершенствованным покрытием в протяженности } \\
\text { автомобильных дорог общего пользования с твердым покрытием, \% }\end{array}$ \\
\hline Северо-Западный федеральный округ & 142080,9 & 53,3 \\
\hline г. Санкт-Петербург & 3412,1 & 92,5 \\
\hline Мурманская область & 3523,4 & 77,8 \\
\hline Калининградская область & 8671,8 & 70,5 \\
\hline Республика Коми & 7595,3 & 68,2 \\
\hline Ленинградская область & 22286,9 & 61,4 \\
\hline Новгородская область & 14877,6 & 55,3 \\
\hline Республика Карелия & 10761,8 & 50,5 \\
\hline Псковская область & 22773,7 & 43,5 \\
\hline Вологодская область & 28531,8 & 42,7 \\
\hline Архангельская область & 19646,5 & 33,9 \\
\hline \multicolumn{3}{|c|}{$\begin{array}{l}\text { * K автомобильным дорогам с усовершенствованным покрытием относятся дороги со следующими видами покрытия: } \\
\text { цементобетонным, ассральтобетонным, из щебня и гравия, обработанных вяжущими материалами. } \\
\text { Источник: данные Федеральной службы государственной статистики РФ. - Режим доступа: http://www.gks.ru/wps/wcm/connect/ } \\
\text { rosstat_main/rosstat/ru/statistics/enterprise/transport/ }\end{array}$} \\
\hline
\end{tabular}

Таблица 8. Ранжирование наиболее значимых фракторов внешней среды, оказывающих влияние на развитие внутреннего туризма Вологодской области

\begin{tabular}{|c|c|c|}
\hline Фактор & К вл. $1^{*}$ & К вл. $2^{*}$ \\
\hline \multicolumn{3}{|l|}{ Политико-правовые фракторы } \\
\hline Наличие программных документов развития сферы туризма & 4,6 & 4,8 \\
\hline Совершенство законодательной базы в сфере туризма & 5,1 & 5,1 \\
\hline Международная обстановка & 5,8 & 4,1 \\
\hline \multicolumn{3}{|l|}{ Экономические фракторы } \\
\hline Уровень доходов населения & 8,8 & 8,8 \\
\hline Уровень инсрляции & 9,0 & 8,0 \\
\hline Покупательная способность населения & 9,3 & 8,3 \\
\hline Финансовое состояние туристских организаций & 6,8 & 6,5 \\
\hline Доступность кредитов для предпринимателей & 5,1 & 4,8 \\
\hline \multicolumn{3}{|l|}{ Социальные факторы } \\
\hline Половозрастная характеристика туристов & 6,6 & 6,0 \\
\hline Уровень образования и квалисрикации кадров индустрии туризма & 8,0 & 8,3 \\
\hline Тенденция к дроблению отпускного времени & 4,5 & 4,6 \\
\hline Численность населения страны & 4,6 & 4,5 \\
\hline \multicolumn{3}{|l|}{ Технологические факторы } \\
\hline Электронная коммерция, системы онлайн-бронирования & 9,0 & 9,5 \\
\hline $\begin{array}{l}\text { Развитие услуг сотовой связи и сети Интернет, распространение беспроводного } \\
\text { Интернета (Wi-Fi) }\end{array}$ & 7,5 & 7,8 \\
\hline Развитие платежных систем, применение мобильных платежей в ссрере туризма & 6,6 & 7,8 \\
\hline $\begin{array}{l}\text { Инновационные технологиив индустрии туризма (транспорт, связь, автоматизированные } \\
\text { системы управления и т.п.). }\end{array}$ & 8,8 & 9,6 \\
\hline \multicolumn{3}{|l|}{$\begin{array}{l}\text { * К вл. } 1 \text { - действие факторов в ближайшей и среднесрочной перспективе (2016-2020 гг.); } \\
\text { * К вл. } 2 \text { - действие факторов в долгосрочной перспективе (2021-2030 гг.). } \\
\text { Источник: составлено автором. }\end{array}$} \\
\hline
\end{tabular}


высших учебных заведений Вологодской области, исследовательская деятельность которых направлена на изучение состояния, тенденций и перспектив развития туризма.

Результаты PEST-анализа, представляющие собой ранжированный ряд наиболее значимых факторов, включающих политические (Policy), экономические (Economy), социальные (Society) и технологические (Technology) аспекты внешней среды, воздействующих на развитие внутреннего туризма Вологодской области в кратко-, средне- и долгосрочной перспективе, представлены в таблице 8 .

Выводы и заключение. Проведенный PEST-анализ показал, что наибольшее влияние на развитие внутреннего туризма в ближайшей и долгосрочной перспективе будут оказывать экономические и технологические факторы. В связи с этим сформированы направления, реализация которых способствует наиболее эффективному развитию данного сегмента рынка в частности и региональному развитию в целом.

Основные задачи при реализации концептуальных направлений развития внутреннего туризма состоят в следующем.

1. Развитие приоритетных внутренних туристских продуктов, в том числе на основе использования развития электронной коммерции, систем он-лайн-бронирования, использовании инноваций. Это позволит увеличить конкурентоспособность туристского продукта региона, дифференцировать его среди аналогичных продуктов конкурентов.

Формирование приоритетных конкурентоспособных туристских продуктов должно основываться на развитии видов туристической деятельности, обеспечивающих рост потока внутренних туристов. Так, например, к числу таких видов туризма относится событийный туризм.
2. Формирование спроса на внутренний туристский продукт, услугу исходя из сложившихся и перспективных потребностей населения в отдыхе и соответствие его требованиям потенциальных потребителей.

Реализовать данное направление возможно за счет использования маркетингового подхода, в частности целевого маркетинга, который предполагает разработку определенного туристского продукта для определенного сегмента потребителей. Во-первых, региональным туристским администрациям необходимо на постоянной основе проводить маркетинговые исследования для выявления потребительских предпочтений потенциальных туристов и последующей сегментации рынка услуг внутреннего туризма. Во-вторых, целесообразно разработать информационную кампанию для рекламы туристских ресурсов региона и формирования среди населения желания путешествовать внутри страны. В-третьих, для повышения качества предоставляемых услуг предлагается формирование региональных стандартов гостеприимства, которые позволят региону создавать имидж и репутацию «гостеприимной территории» как в глазах туриста, так и в глазах местного населения. При этом создание подобного кодекса можно возложить на научные или образовательные организации региона.

3. Формирование доступного по цене предложения качественного внутреннего туристского продукта на базе существующих и перспективных туристских ресурсов региона. При реализации данного направления местным органам власти необходимо проводить политику, направленную на улучшение отношений с субъектами туристского бизнеса и включающую такие меры, как:

- предоставление льгот по налогообложению; 
- предоставление гарантий при получении кредитов и займов;

- включение турфирм в региональные проекты по развитию туризма.

Таким образом, результаты данного исследования состоят в определении наибо- лее эффективных направлений развийжя внутреннего туризма в регионе с учетом экономической турбулентности и могут быть использованы региональными органами власти при разработке соответствующих программ.

\section{Литература}

1. Анчукова, Н.В. Туризм в экономике региона [Текст] / Н.В. Анчукова, О.С. Москвина. - Вологда: ВНКЦ ЦЭМИ РАН, 2002. - $72 \mathrm{c}$.

2. Гранберг, А.Г. Основы региональной экономики [Текст] : учеб. для вузов. - 5-е изд. / А.Г. Гранберг.- М. : ГУ ВШЭ, 2006. - 495 с.

3. Григоренко, Т.Н. Приоритеты в области развития внутреннего и въездного туризма России на современном этапе [Текст] / Т.Н. Григоренко, Л.Н. Казьмина // Вестник Национальной академии туризма. - 2015. - № 4. - С. 14-17.

4. Квартальнов, В.А. Туризм [Текст]: учебник / В.А. Квартальнов. - М.: Финансы и статистика, 2002. - 320 с.

5. Кошелева, А.И. Туристско-рекреационный комплекс Крыма: проблемы и перспективы развития в переходный период / А.И. Кошелева // Регион: экономика и социология. - 2015. - № 3. - С. 239-254.

6. Кружалин, В.И. Состояние российского туризма, проблемы и перспективы [Текст] / В.И. Кружалин, К.В. Кружалин, Н.В. Шабалина // Вестник Национальной академии туризма. - 2016. - № 1. - С. 10-13.

7. Макеева, Д.Р. Экономика туризма России на современном этапе: от выездного туризма к ориентированному на внутренний рынок [Текст] / Д.Р. Макеева // Вопросы региональной экономики. - 2015. № 1. - C. 39-48.

8. Население России в 2016 году: доходы, расходы и социальное самочувствие. Мониторинг НИУ ВШЭ. Июль 2016 / под ред. Л.Н. Овчаровой. - М.: НИУ ВШЭ, 2016.

9. Семенова, Е.В. Проблемы развития внутреннего туризма и некоторые пути их решения [Текст] / Е.В. Семенова, Н.В. Маслова // Вестник Национальной академии туризма. - 2016. - № 3. - С. 34-36.

10. Стратегические ориентиры экономического развития России [Текст] / Р.С. Гринберг, А.Я. Рубинштейн, Л.И. Абалкин, С.Ю. Глазьев, В.Л. Макаров [и др.]. - СПб. : Алетейя, 2010. - 664 с.

11. Стратегия развития туризма в Вологодской области [Текст] / В.А. Ильин, Ю.Н. Плеханов, Т.В. Ускова, С.А. Селякова, Л.В. Дубиничева, К.В. Марков, Е.Н. Богачева. - Вологда: ВНКЦ ЦЭМИ РАН, 2009. - 187 с.

12. Татаркин, А.И. Оценка инвестиционных потребностей социально-экономического развития региона [Текст] / А.И. Татаркин, М.Р. Биматов // Журнал экономической теории. - 2010. - № 2. - С. 29-33.

13. Ускова, Т.В. Социально-экономический ресурс туризма [Текст]: монография / Т.В. Ускова, Л.В. Дубиничева, В.С. Орлова. - Вологда: ИСЭРТ РАН, 2011. - 182 с.

14. Гулин, К.А. К вопросу о социально-экономической модернизации российских регионов / К.А. Гулин // Экономические и социальные перемены: факты, тенденции, прогноз. - 2012. - № 4 (22). - С. 42-58.

15. Проблемы экономического роста территории [Текст]: монография / Т.В. Ускова, Е.В. Лукин, Т.В. Воронцова, Т.Г. Смирнова; под рук. Т.В. Усковой. - Вологда: Ин-т социально-экономического развития территорий РАН, 2013. $-170 \mathrm{c}$.

16. Черникова, Л.И. К вопросу переориентации на внутренний туризм [Текст] / Л.И. Черникова, Г.Р. Фаизова // Финансовая аналитика: проблемы и решения. - 2016. - С. 52-60.

17. American Express Spending \& Saving Tracker [Electronic resource]. - Available at: http://about. americanexpress.com/news/sst

18. Economic Impact of Travel \& Tourism 2015 [Electronic resource]. - Available at : http://www.wttc.org/research/ economic-research/economic-impact-analysis

19. Falk, J. H., Travel and learning: Aneglected tourism research area [Text] / J. H. Falk, R. Ballantyne, J. Packer, P. Benckendorff // Annals of Tourism Research. - 2012. - № 39. - Pp. 908-927.

20. International tourism [Electronic resource]. - Available at : http://www.worldbank.org/en/country/russia

21. Antonakakis, N. Tourism and economic growth: Does democracy matter? [Text] / N. Antonakakis, M. Dragouni, B. Eeckels, G. Filis // Annals of Tourism Research. - 2016. - № 39. - Pp. 231-267. 


\title{
Сведения об авторах
}

Екатерина Георгиевна Леонидова - младший научный сотрудник, Институт социальноэкономического развития территорий Российской академии наук (Российская Федерация, 160014, г. Вологда, ул. Горького, д. 56a; e-mail: leo_leg_8509@mail.ru)

Leonidova E.G.

\section{Domestic Tourism Development in a Region}

\begin{abstract}
Tourism is a sector which has a significant impact on the socio-economic development of territories. This type of national economic activity is characterized by a multiplier effect, generating incomes in related economic sectors. Among all types of tourism, the key role belongs to domestic tourism as the main source of income from tourist activities. Russian regions, domestic tourism is poorly developed due to imperfect infrastructure of the sector, lack of correlation between prices for tourism products and their quality, and lack of qualified personnel. In recent years, external factors are of particular significance for this sector; they include turbulent geopolitical situation in some countries, crisis phenomena in the economy, ban on travelling to popular foreign resorts for Russian citizens. The issues of domestic tourism development are reflected in works by D.R. Makeeva, E.V. Semenova, N.V. Maslova, L.I. Chernikova, G.R. Faizov. The purpose for the research is to study directions for domestic tourism development in the region taking into account the influence of external factors. The author uses scientific methods of comparison, generalization, analysis, synthesis, PEST-analysis, and the method of expert survey. Statistical data analysis helped reveal the reduction in the number of Russians' tourist trips and a simultaneously increasing demand for hotel services in the country. It has been revealed that the currently available tourism potential helps develop a wide range of types of domestic tourism. The reasons hindering domestic tourism development are lack of tourism products in the region which would attract domestic tourists; inadequate tourist infrastructure and the population's lack of funds for tourist trips. In conclusion, based PEST-analysis, the author specifies directions which ensure efficient domestic tourism development in the region, taking into account the economic and geopolitical situation.
\end{abstract}

Key words: tourism, domestic tourism, region, economy.

\section{References}

1. Anchukova N.V., Moskvina O.S. Turizm v ekonomike regiona [Tourism in region's economy]. Vologda: VNKTs TsEMI RAN, 2002. 72 p. (In Russian).

2. Granberg A.G. Osnovy regional'noi ekonomiki: ucheb. dlya vuzov [Basics of regional economy: textbook for higher education institutions]. 5th edition. Moscow: GU VShE, 2006. 495 p. (In Russian).

3. Grigorenko T.N., Kaz'mina L.N. Prioritety v oblasti razvitiya vnutrennego i v"ezdnogo turizma Rossii na sovremennom etape [Priorities in domestic and inbound tourism development in Russia at the present stage]. Vestnik natsional'noi akademii turizma [Bulletin of National Tourism Academy], 2015, no. 4, pp. 14-17. (In Russian).

4. Kvartal'nov V.A. Turizm: uchebnik [Tourism: textbook]. Moscow: Finansy i statistika, 2002. 320 p. (In Russian).

5. Kosheleva A.I. Turistsko-rekreatsionnyi kompleks Kryma: problemy i perspektivy razvitiya v perekhodnyi period [Tourist and recreational complex of Crimea: problems and prospects of development in the transition period]. Region: ekonomika i sotsiologiya [Region: economics and sociology], 2015, no. 3, pp. 239-254. (In Russian).

6. Kruzhalin V.I., Kruzhalin K.V., Shabalina N.V. Sostoyanie rossiiskogo turizma, problemy i perspektivy [Current state, problems and prospects of Russian tourism]. Vestnik natsional'noi akademii turizma [Bulletin of National Tourism Academy], 2016, no. 1, pp. 10-13. (In Russian). 
7. Makeeva D.R. Ekonomika turizma Rossii na sovremennom etape: ot vyezdnogo turizma k orientirovanhacongu na vnutrennii rynok [Russian tourism economy at the present stage: from outbound to the internal focus on the domestic market]. Voprosy regional'noi ekonomiki [Problems of regional economy], 2015, no. 1, pp. 39-48. (In Russian).

8. Ovcharova L.N. (Ed.). Naselenie Rossii v 2016 godu: dokhody, raskhody $i$ sotsial'noe samochuvstvie. Monitoring NIU VShE. Iyul' 2016 [Russian population in 2016: income, expenditures and social well-being. Moscow Higher School of Economics Monitoring. July 2016]. Moscow: NIU VShE, 2016. (In Russian).

9. Semenova E.V., Maslova N.V. Problemy razvitiya vnutrennego turizma i nekotorye puti ikh resheniya [Problems of domestic tourism development and some ways of their solution]. Vestnik natsional'noi akademii turizma [Bulletin of National Tourism Academy], 2016, no. 3, pp. 34-36. (In Russian).

10. Grinberg R.S., Rubinshtein A.Ya., Abalkin L.I., Glaz'ev S.Yu., Makarov V.L. et al. Strategicheskie orientiry ekonomicheskogo razvitiya Rossii [Strategic benchmarks of Russia's economic development]. Saint-Petersburg: Aleteiya, 2010. 664 p. (In Russian).

11. Ilyin V.A., Plekhanov Yu.N., Uskova T.V., Selyakova S.A., Dubinicheva L.V., Markov K.V., Bogacheva E.N. Strategiya razvitiya turizma $v$ Vologodskoi oblasti [Tourism development strategy in the Vologda Oblast]. Vologda: VNKTs TsEMI RAN, 2009. 187 p. (In Russian).

12. Tatarkin A.I., Bimatov M.R. Otsenka investitsionnykh potrebnostei sotsial'no-ekonomicheskogo razvitiya regiona [Assessment of investment needs of the region's socio-economic development]. Zhurnal ekonomicheskoi teorii [Russian journal of economic theory], 2010, no. 2, pp. 29-33. (In Russian).

13. Uskova T.V., Dubinicheva L.V., Orlova V.S. Sotsial’no-ekonomicheskii resurs turizma: monografiya [Socioeconomic tourist resources: monograph]. Vologda: ISERT RAN, 2011. 182 p. (In Russian).

14. Gulin K.A. K voprosu o sotsial'no-ekonomicheskoi modernizatsii rossiiskikh regionov [On the issue of socioeconomic modernization of Russian regions]. Ekonomicheskie i sotsial'nye peremeny: fakty, tendentsii, prognoz [Economic and social changes: facts, trends, forecast], 2012, no. 4 (22), pp. 42-58. (In Russian).

15. Lukin E.V., Vorontsova T.V., Smirnova T.G. Problemy ekonomicheskogo rosta territorii: monografiya [Problems of territories' economic growth: monograph]. Under academic supervision of Uskova T.V. Vologda: In-t sotsial'noekonomicheskogo razvitiya territorii RAN, 2013. 170 p. (In Russian).

16. Chernikova L.I., Faizova G.R. K voprosu pereorientatsii na vnutrennii turizm [On the re-focusing on domestic tourism]. Finansovaya analitika: problemy i resheniya [Financial Analytics: Science and Experience], 2016, pp. 52-60. (In Russian).

17. American Express Spending \& Saving Tracker. Available at: http://about.americanexpress.com/news/sst

18. Economic Impact of Travel \& Tourism 2015. Available at: http://www.wttc.org/research/economic-research/ economic-impact-analysis

19. Falk J. H., Ballantyne R., Packer J., Benckendorff P. Travel and learning: Aneglected tourism research area. Annals of Tourism Research, 2012, no. 39, pp. 908-927.

20. International tourism. Available at: http://www.worldbank.org/en/country/russia

21. Antonakakis N., Dragouni M., Eeckels B., Filis G. Tourism and economic growth: Does democracy matter? Annals of Tourism Research, 2016, no. 39, pp. 231-267.

\section{Information about the Author}

Ekaterina Georgievna Leonidova - Junior Research Associate, Institute of Socio-Economic Development of Territories of Russian Academy of Science (56A, Gorky Street, Vologda, 160014, Russian Federation; e-mail: leo_leg_8509@mail.ru)

Статья поступила 07.02.2017. 